\title{
KORELASI ANTARA BUDAYA SUSAH ANTRE TERHADAP PENYEBARAN COVID-19 DI INDONESIA
}

\author{
Elisabeth Filandow, Kezia Kanaya Clairine, Hasim Asyari, Fikra Asyrafi \\ Institut Teknologi Bandung \\ Email : 13620069@mahasiswa.itb.ac.id
}

\begin{abstract}
Abstrak
Antre bukan merupakan hal yang baru bagi masyarakat Indonesia. Namun, antre sebagai suatu kebiasaan baik tampak asing penerapannya dalam kegiatan sehari-hari dan "susah antre" seperti sudah menjadi budaya di Indonesia. Penerapan kebiasaan antre dapat membawa dampak positif, terutama di masa pandemi COVID-19. Kondisi budaya antre di Indonesia selama pandemi dianalisis menggunakan metode kuantitatif melalui survei, sedangkan keterkaitan budaya antre dalam pencegahan penyebaran virus corona ditentukan melalui studi literatur. Pada kenyataannya esensi mengantre belum tercerminkan oleh masyarakat Indonesia. Padahal, penerapan budaya antre mendukung pelaksanaan protokol kesehatan yang ditetapkan oleh pemerintah seperti social distancing sehingga dapat membantu pencegahan penyebaran virus corona di Indonesia. Untuk membentuk suatu budaya antre yang disiplin dan tertib di Indonesia, kebiasaan mengantre penting ditanamkan sejak masa kanakkanak. Selain itu, hukuman moral seperti pemberian rasa malu kepada pihak yang tidak bersedia mengantre dapat dilakukan di lingkungan masyarakat.
\end{abstract}

Kata kunci: Antre, COVID-19, Protokol Kesehatan

\begin{abstract}
A queue is not an uncommon event for Indonesian. However, queue as a good habit is still a foreign practice in everyday life. "Hard to queue" seems to have become Indonesian culture. Queuing brings positive impacts, especially in the COVIDovid-19 pandemic. Queuing habits in Indonesia during the pandemic are analyzed with a quantitative method through a survey. The relation between queue culture with the prevention of coronavirus spread is determined with the literature study method. In reality, the essence of queuing has not been reflected by Indonesian. In fact, the implementation queue culture supports the implementation of health protocols set by the government, such as social distancing. Thus, it can help prevent the spread of coronavirus in Indonesia. To create a disciplined queue culture in Indonesia, the implantation of queuing habits is essential from childhood. In addition, moral punishment such as giving shame to those who are unwilling to queue can be carried out in the community.
\end{abstract}

Keywords: Queue, COVID-19, Health Protocols

\section{PENDAHULUAN}

Antrean dapat ditemui di toilet umum, bank, tempat perbelanjaan, wahanan permainan, rumah sakit, dan lainnya. Antrean-antrean tersebut merupakan hasil dari aturan ketertiban yang dikontruksi dan tertanam dalam perilaku masyarakat (Ghandi, 2013) (Rachman, Ryan, et al., 2021). Meskipun penerapan sistem antrean sudah banyak dilakukan di Indonesia, dalam pelaksaannya masyarakat masih asing dalam memaknai kedisiplinan mengantre. Sering dijumpai kasus ketika masyarakat baru akan mengantre jika mengantre bukan sebuah pilihan, melainkan aturan.

Dalam masa pandemi COVID-19 masyarakat memiliki kewajiban untuk mematuhi protokol kesehatan, salah satunya social distancing atau jaga jarak. Penerapan social distancing memerlukan kesadaran penuh dari setiap anggota masyarakat terhadap esensi mengantre (Dewantara \& Nurgiansah, 2021b). Pada kenyataannya perilaku susah antre tidak terkecuali pada masa pandemi COVID-19, seolah-olah perilaku tersebut sudah menjadi budaya dari masyarakat Indonesia. 
Padahal, penanaman budaya antre yang baik dapat mendukung kepatuhan masyarakat terhadap social distancing, sehingga membantu pencegahan penyebaran virus corona.

Salah satu contoh kejadian serupa terjadi di Poliklinik Pinere, Banda Aceh, yang menyediakan fasilitas penanganan pasien COVID-19. Poliklinik tersebut mendapat keluhan atas ketidaktertiban antrean, sehingga pihak Rumah Sakit Umum Daerah dr. Zainoel Abidin harus turun tangan untuk memeperketat sistem antrean. Pemberlakuan sistem antrean yang tertib dan sesuai dengan protokol kesehatan ditujukan untuk mencegah penyebaran COVID-19 (Safrina, 2020) (Dewantara \& Nurgiansah, 2021c).

Akibat dari permasalahan yang telah dibahas sebelumnya, dalam penelitian ini penulis mengkaji hubungan antara budaya susah antre masyarakat Indonesia dengan penyebaran virus corona (Dewantara \& Nurgiansah, 2021a). Penelitian dilakukan untuk meningkatkan pemahaman masyarakat umum mengenai pentingnya penerapan kedisiplinan dalam mengantre untuk membantu mencegah penularan COVID-19. Selain itu, penelitian diharapkan dapat membantu pihak-pihak terkait dalam menyusun dan mengembangkan kebijakan sistem antrean melalui perilaku masyarakat Indonesia dalam mencegah penularan COVID-19.

\section{METODE PENELITIAN}

Metode Penelitian yang digunakan pada penelitian kali ini adalah gabungan dari metode penelitian kualitatif berupa studi literasi dan metode penelitian kuantitatif berupa survei. Studi literasi merupakan penelitian yang dilakukan oleh peneliti dengan mengumpulkan sejumlah buku buku, majalah yang berkaitan dengan masalah dan tujuan penelitian (Danial dan Warsiah, 2009:80). Studi literasi juga studi kepustakaan adalah dilakukan mencari data atau informasi riset melalui membaca jurnal ilmiah, buku-buku referensi dan bahan bahan publikasi yang tersedia di perpustakaan (Ruslan, 2008:31) (Rachman, Nurgiansah, et al., 2021). Untuk memperoleh informasi yang berkaitan dengan topik atau masalah yang akan dibahas dalam tulisan ini, penulis menggunakan studi literasi. Upaya mengumpulkan informasi diperoleh dari buku-buku ilmiah, laporan penelitian, karya-karya ilmiah, peraturan-peraturan, ketetapan-ketetapan, dan sumber-sumber tertulis baik tercetak maupun elektronik lain.

Selain itu, penulis juga menggunakan metode penelitian secara kuantitatif yaitu melalui survei, yaitu metode penelitian yang memilih sampel dari populasi tertentu dengan menggunakan kuesioner sebagai alat untuk mengumpulkan data yang pokok. Penelitian ini merupakan suatu riset kuantitatif yang akan diolah oleh penulis untuk mendapatkan hasil yang ingin diperoleh. Lokasi penelitian diadakan secara daring dan waktu penelitian dilakukan sejak tanggal 14 September 2021.

\section{HASIL PENELITIAN DAN PEMBAHASAN Hasil Penelitian}
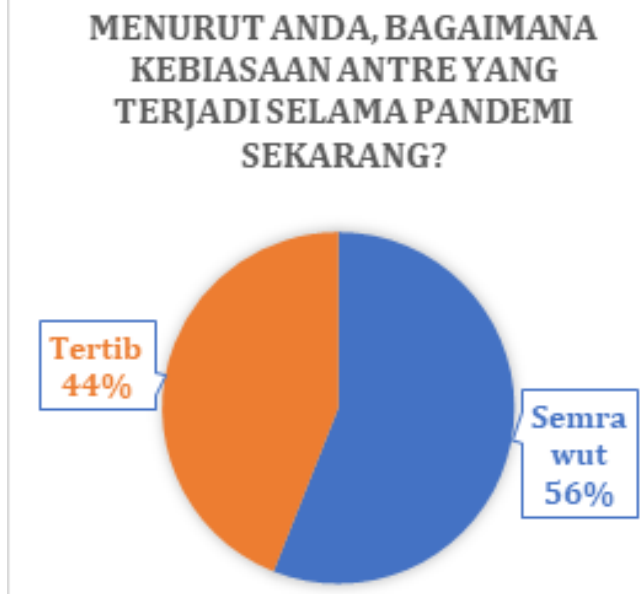

Gambar 1. Hasil Penelitian Peristiwa Budaya Antre 
Menurut hasil data yang kami peroleh dari survei sebanyak 25 responden, sebanyak $56 \%$ dari 25 orang menjawab antrean selama pandemi masih semrawut (berantakan), sedangkan $44 \%$ dari 25 orang menjawab antrean sudah tertib.

\section{APAKAH TERDAPAT KORELASI ANTARA BUDAYA ANTRE DENGAN PROTOKOL KESEHATAN YANG DIEDARKAN OLEH PEMERINTAH ?}

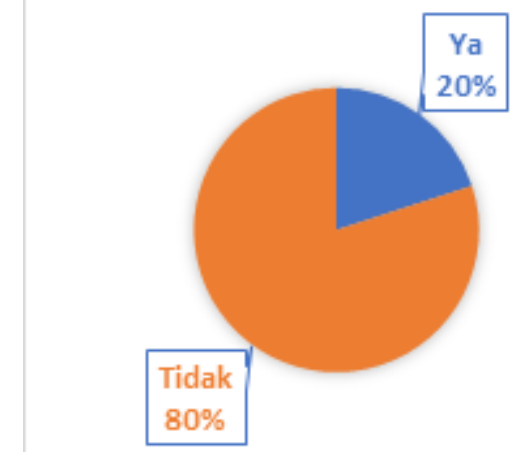

Gambar 2. Hasil Penelitian Korelasi Budaya Antre

Selain itu, berdasarkan data survei sebanyak $20 \%$ dari 25 responden menjawab ya, sedangkan $80 \%$ lainnya menjawab tidak ada hubungan antara budaya antre dengan protokol kesehatan yang diedarakn oleh pemerintah.

\section{Pembahasan}

\section{Budaya Antre dan Manfaatnya}

E.B Taylor dalam Soekanto (1996:55) (Dewantara, Hermawan, et al., 2021) menyatakan kebudayaan sebagai kompleks yang meliputi pengetahuan kepercayaan, kesenian, moral, hukum, adat istiadat, dan kemampuan lain yang diperoleh manusia sebagai bagian dari masyarakat. Hidayah (1996:12) mendefinisikan antre sebagai aktivitas sekumpulan orang secara bergiliran untuk memperoleh suatu kesempatan atau barang sesuai dengan urutan di tempat-tempat tertentu. Keterbatasan kapasitas pelayanan dan kebutuhan terhadap layanan yang sama mendorong pembentukan antrean. Dengan demikian, budaya antre merupakan kebiasaan dalam masyarakat untuk memperoleh kesempatan dan layanan yang sama secara bergiliran menurut urutan.

Chairilsyah (2015) (Dewantara, Nurgiansah, et al., 2021) mengemukakan unsur-unsur pokok yang melandasi budaya antre meliputi unsur minat dan kebutuhan, unsur keterbatasan, dan unsur kesepakatan. Unsur minat dan kebutuhan menggambarkan bahwa antre diakibatkan oleh kesamaan minat dan kebutuhan dari orang-orang. Selain itu, kesamaan minat dan kebutuhan terjadi pada suatu waktu tertentu dan terdapat keterbatasan sumber daya atau kapasitas pelayanan (unsur keterbatasan) sehingga mengharuskan orang-orang berkepentingan untuk mendapatkan sumber daya atau pelayanan secara bergiliran. Unsur kesepakatan dalam budaya antre ditunjukkan dengan adanya kesepakatan yang harus ditaati, baik tertulis maupun tidak tertulis, bahwa pelayanan atau sumber daya akan diberikan kepada orang yang datang terlebih dahulu.

Kebiasaan mengantre dapat memberikan manfaat bagi pihak-pihak yang melakukan seperti melatih emosi, ketertiban, kejujuran, disiplin, memiliki rasa malu, taat hukum, dan menghormati serta menghargai hak orang lain (Chairilsyah, 2015; Oky, 2019). Pada dasarnya, prinsip dari mengantre adalah orang yang datang terlebih dahulu memiliki hak untuk mendapat pelayanan atau sumber daya terlebih dahulu. Bila seseorang menyerobot antrean artinya orang tersebut merampas hak orang lain. Pada kejadian inilah dengan 
membudayakan mengantre akan tumbuh rasa malu untuk menyerobot antrean, melatih emosi dengan cara bersabar, dan menahan ego untuk mendahulukan diri sendiri dibandingkan dengan orang lain.

Dalam hal pemberlakuan social disancing, budaya antre dapat meningkatkan ketertiban dari masyarakat untuk mempertahankan jarak antara satu dengan yang lain. Masyarakat menjadi taat dengan protokol kesehatan karena menghargai hak orang lain dan lebih sabar dalam menunggu giliran. Seringkali alasan seseorang tidak mau mengantre adalah sedang terburu-buru. Pernyataan tersebut juga merupakan hal yang egois karena untuk mementingkan keadaan terdesaknya, orang lain terpaksa mendahulukannya, kecuali dalam keadaan darurat (Nurgiansah, 2020b). Dengan sadar bahwa di tempat-tempat yang akan dituju harus mengantre, orang tersebut dapat lebih disiplin dalam mengatur waktu. Dengan demikian, orang tersebut dapat tiba lebih awal dan dengan adil mendapat sumber daya atau pelayanan terlebih dahulu.

\section{Peristiwa Budaya Antre Selama Pandemi COVID-19}

Pada masa pandemi COVID-19, banyak sekali antrean yang masih tidak tertib dan berkerumun dimana-mana. Contoh yang pertama adalah kerumunan ojek online ketika McDonalds merilis menu baru yang bekerja sama dengan boyband asal korea selatan, BTS, pada tanggal 9 Juni 2021. Para penggemar BTS sangat menginginkan dan mengincar menu terbaru dari McDonalds tersebut agar mereka bisa mengonsumsi, memfoto, dan memposting makanan hasil dari pembelian mereka melalui ojek online ke media sosial seperti Instagram dan Twitter. Banyak sekali penggemar BTS yang membeli lewat ojek online hingga antrean untuk mendapatkan makanan tersebut membludak di daerah Jabodetabek (Nurgiansah, 2021d).

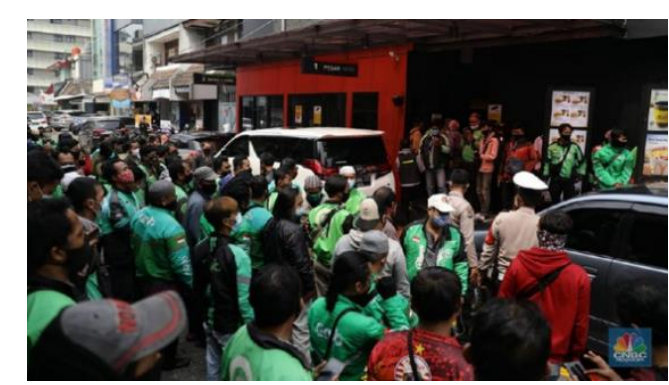

Gambar 3. Kerumunan Antrean Ojek Online di Depan McDonalds

Salah satu contoh kerumunan antrean akibat banyak penggemar BTS yang memesan makanan McDonalds yang berkolaborasi dengan BTS lewat aplikasi ojek online terdapat pada gambar 1 yang berlokasi di gerai McDonalds cabang pondok indah. Pada gambar tersebut terlihat para pengendara ojek online mengantre dengan sangat ramai dan terdapat polisi yang bertugas untuk menertibkan antrean para pengendara ojol. Mereka mengantre selama berjam-jam untuk mendapatkan pesanan dari McDonalds untuk para penggemar BTS (Nurgiansah, 2021c).

Selain itu, contoh yang lain adalah kerumunan yang terjadi akibat antrean untuk membeli tiket masuk di Kebun Binatang Bandung. Pada hari minggu tanggal 16 Mei 2021, sebanyak 4.427 orang berkerumun untuk membeli tiket masuk Kebun Binatang Bandung. Walaupun memakai masker, tetapi jaga jarak diabaikan oleh mereka yang mengunjungi kebun binatang bandung. Pemkot Kota Bandung melakukan tes swab antigen kepada beberapa pengunjung dan hasilnya 6 orang reaktif COVID-19 (Nurgiansah, 2020c).

Pemkot Kota Bandung menyatakan tidak menutup tempat wisata kebun binatang bandung. Walaupun begitu, terdapat penutupan akses jalan yang 
dilakukan oleh kepolisian setempat di jalan tamansari agar mengurangi mobilitas. penutupan akses jalan yang dilakukan oleh kepolisian setempat dalam implementasinya kurang efektif karena banyak orang yang bisa melewati itu dengan berjalan kaki ke kebun binatang Bandung. Oleh karena itu, Walikota Bandung menyarankan agar dilakukan akses buka tutup jalan agar pelaksanaannya efektif (Nurgiansah, 2021a).

\section{Korelasi Budaya Antre dengan Protokol Kesehatan yang Diedarkan oleh Pemerintah}

Dalam menghadapi pandemi COVID-19, protokol kesehatan utama yang diedarkan oleh pemerintah adalah pembatasan sosial (social distancing). Hal ini juga dihimbau oleh World Health Organization (WHO) untuk dilakukan di seluruh dunia. Tujuan dari pembatasan sosial tidak lain adalah untuk memutus mata rantai COVID-19 yang hanya bisa hidup jika memiliki inang, dalam hal ini adalah melalui manusia. Oleh karena itu, salah satu bentuk dari pembatasan sosial yang berlangsung di masyarakat adalah budaya antre.

Walaupun protokol kesehatan telah diedarkan dan telah dilakukan oleh sebagian masyarakat, namun banyak orang tidak menghiraukan budaya social distancing terutama dalam kegiatan mengantre. Hal ini dikarenakan, sekalipun COVID-19 sangat meresahkan bagi masyarakat terkait dengan kesehatan dan keselamatan diri, namun ikatan relasi sosial masih lebih kuat dalam perspektif masyarakat.

Menurut (Wiwoho, 2020) terdapat dua contoh penerapan bagi masyarakat Indonesia dimana budaya social distancing ini masih sangat sulit untuk diterapkan. Pertama, masyarakat kesulitan menjalankan social distancing karena kebiasaan dalam kebersamaan, kerja sama, solidaritas, dan sejenisnya sebagai bentuk dari interaksi sosial bagi masyarakat Indonesia. Kedua, bagi masyarakat awam beranggapan social distancing hanya sebatas menjaga jarak, terlihat pada saat ketika berada di area publik seperti ketika melakukan antrean di anjungan tunai mandiri (ATM). Meskipun, kondisi seperti ini masih menjadi masalah pribadi karena masih ada masyarakat yang tidak mudah untuk melakukannya. Dengan kata lain, terlihat dengan sangat jelas ada persoalan yang sementara dihadapi oleh masyarakat terkait dengan social distancing.

Menurut (Simanjuntak \& Fitriana, 2020) (Nurgiansah, 2021b), penerapan budaya antre pada masa pandemi ini tentulah semakin sulit, karena semakin banyak masyarakat yang tidak sabar untuk menunggu antrean karena dengan adanya protokol kesehatan, maka panjang dari suatu antrean tentunya lebih panjang dan kapasitas untuk memasuki suatu tempat tentu saja lebih sedikit dibandingkan zaman sebelum terjadi pandemi COVID-19. Oleh karena itu, kesadaran agar masyarakat melaksanakan budaya antre merupakan suatu tantangan juga untuk memajukan negara kita.

Padahal, hal ini sangat penting untuk mencegah terjadinya kematian masyarakat secara massal bahkan hilangnya sebuah generasi, karena pada kenyataannya, COVID-19 bisa berakibat fatal pada usia produktif. Menurut (Admin Humas, 2021) (Nurgiansah, 2020a), jika satu orang terinfeksi yang tidak melakukan jaga jarak maka mengakibatkan 406 orang lainnya tertular pada hari ke-30. Akan tetapi, jika mengurangi kontak sosial sebesar 50 persen, jumlah masyarakat yang terinfeksi dapat turun menjadi 15 orang pada periode waktu yang sama. Bahkan, jika kontak sosial satu orang terinfeksi berkurang hingga $75 \%$, laju penyebaran virus corona bisa lebih ditekan lagi hingga 2,5 orang pada hari ke-30. 


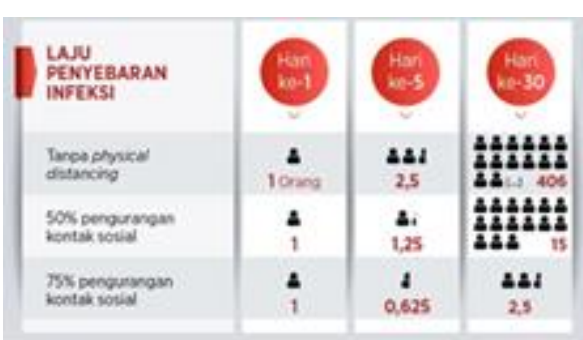

Gambar 4. Grafik Laju Penyebaran Infeksi

Terdapat beberapa alasan betapa pentingnya menjaga jarak dengan orang lain seperti menghindari risiko terkena droplet. Sumber penularan melalui droplet ini dapat terjadi ketika sedang berbicara dengan orang lain, batuk, dan bersin. Selain itu, dengan menjaga jarak, kita dapat membantu tenaga medis yang sedang berjuang untuk melawan COVID-19 sebelum terlambat. Apabila kita menjaga protokol menjaga jarak ini, kita dapat melindungi anggota keluarga di rumah dan memutuskan rantai penularan. Dengan disiplin menjaga jarak, grafik penularan COVID-19 dapat menurun.

Menurut (Sari, 2021; Setyani, 2021), di tengah masa pandemi ini, banyak bantuan sembako dari pemerintah ataupun dari para dermawan lainnya yang ingin membagikan bantuan kepada orang banyak tentunya dengan menerapkan protokol kesehatan. Tetapi, banyak masyarakat yang tidak menghiraukan hal ini, sehingga pembagian sembako ini yang telah disusun rapih menjadi tidak beraturan dan berantakan. Hal ini menyebabkan masyarakat menjadi berkerumun untuk mendapatkan bantuan tersebut. Tidak hanya pada saat pembagian sembako, dalam menjalankan kehidupan sehari-hari pun seperti di transportasi umum misalkan di busway, KRL, Supermarket, MRT banyak masyarakat yang masih tidak memiliki kesadaran dalam membudayakan budaya mengantre, walaupun pemerintah pusat sudah memberikan garis antrean sebagai upaya agar masyarakat dapat mengantre dengan tertib. Selain di transportasi umum, kebudayan mengantre masyarakat yang kurang tertib di pasar swalayan akan mengganggu pelanggan lainnya dalam berbelanja.

Dengan budaya antre yang tidak tertib, maka social distancing yang diharapkan tidak akan tercapai dan tingkat penularan COVID-19 akan semakin meningkat. Begitu pula sebaliknya, apabila masyarakat Indonesia dapat menerapkan budaya antre di setiap tempat, maka tingkat penularan COVID-19 akan menurun.

\section{KESIMPULAN}

Budaya antre merupakan hal yang sangat sederhana. Akan tetapi, jika dilihat secara nyata dilapangan penerapanya sampai sekarang masih minim di Indonesia. Hal tersebut terjadi karena kurangnya kesadaran dari masyarakat akan kedisiplinan mengantre. Pada dasarnya, sikap disiplin sendiri membuat berbagai hal menjadi teratur dan tertib, tidak terkecuali dengan antrean. Bayangkan, apabila kesemrawutan antrean terjadi di masa sekarang, tentu lonjakan infeksi virus akan semakin tinggi lagi. Mengingat, penyebaran virus ini tidak lepas dengan kerumunan orang. Dengan antrean yang tertib ditambah kewaspadaan diri akan membantu mencegah penularan COVID-19. Protokol Kesehatan yang terus digalakkan oleh pemerintah akan efektif bila diiringi dengan kesadaran masyarakat akan pentingnya disiplin diri. Apalagi, dengan adanya rencana penerapan adaptasi kebiasaan baru (AKB) yang belum lama ini juga digaungkan oleh pemerintah.

Dengan kedisiplinan yang baik dalam mengantre, bukan tidak mungkin kita akan dapat bertahan dengan situasi pandemi sekarang atau bahkan tantangan-tantangan wabah yang kemungkinan terjadi di masa mendatang. Terkait dengan penelitian ini terdapat kekurangan seperti jumlah responden dalam survei yang dilakukan. Oleh karena itu, penulis berharap masukan dan saran yang akan berguna pada 
penelitian selanjutnya. Selain itu, penulis juga mengucapkan terimakasih kepada pihak-pihak yang terlibat dalam penelitian, khususnya kepada responden survei terkait sampel data yang digunakan penelitian.

\section{DAFTAR PUSTAKA}

Bestari, N. P. (2021, June 9). Gara-gara BTS Meal, Antrean Ojol Mengular di McD. CNBC Indonesia. https://www.cnbcindonesia.com/tech/20210609130316-37-251742/garagara-bts-meal-antrean-ojol-mengular-di-mcd

BeritaSatu.com. (2021, May 17). Terjadi Kerumunan, Pemkot Bandung Tidak Tutup Tempat Wisata. https://www.beritasatu.com/nasional/774875/terjadi-kerumunan-pemkotbandung-tidak-tutup-tempat-wisata

Dewantara, J. A., Hermawan, Y., Yunus, D., Prasetiyo, W. H., Efriani, Arifiyanti, F., \& Nurgiansah, T. H. (2021). Anti-Corruption Education as an Effort to Form Students With Character Humanist and Law-Compliant. Jurnal Civics: Media Kajian Kewarganegaraan, 18(1), 70-81.

Dewantara, J. A., \& Nurgiansah, T. H. (2021a). Building Tolerance Attitudes Of PPKN Students Through Multicultural Education Courses. Jurnal Etika Demokrasi, 6(1), 103-115.

Dewantara, J. A., \& Nurgiansah, T. H. (2021b). Peningkatan Keaktifan Belajar Melalui Penerapan Model Picture And Picture Dalam Pembelajaran PPKn di Sekolah Dasar. Jurnal Publikasi Pendidikan, 11(3), 234-241.

Dewantara, J. A., \& Nurgiansah, T. H. (2021c). Strengthening Pancasila Values During the Covid19 Pandemic. Edukatif: Jurnal Ilmu Pendidikan, 3(4), 2411-2417.

Dewantara, J. A., Nurgiansah, T. H., \& Rachman, F. (2021). Mengatasi Pelanggaran Hak Asasi Manusia dengan Model Sekolah Ramah HAM (SR-HAM). Edukatif: Jurnal Ilmu Pendidikan, $3(2), 261-269$.

Gandhi, A. (2013). Standing Still and Cutting in Line - The Culture of the Queue in India. South Asia Multidisciplinary Academic Journal, 11-18. https://doi.org/10.4000/samaj.3519

Humas, A. (2021, August 29). Pentingnya Menjaga Jarak Dimasa pandemi covid-19. TribrataNews.com. Retrieved November 16, 2021, from https://tribratanews.polri.go.id/read/12022/40/pentingnya-menjaga-jarak-dimasapandemi-covid19-1630217311.

Margareht, T. (2019). Budaya Antri Mempengaruhi Tolak Ukur Suatu Bangsa. Winnetnews, Edukasi Umum. Retrieved from https://www.winnetnews.com/post/budaya-antrimempengaruhi-tolak-ukur-suatu-bangsa

Nurgiansah, T. H. (2020a). Build An Attitude of Nationalism Students At SDN 7 Kadipaten With The Method of Discusion In The Subject PPKn. Jurnal Serunai Pendidikan Pancasila Dan Kewarganegaraan STKIP Budi Daya Binjai, 9(1), 1-11.

Nurgiansah, T. H. (2020b). Fenomena Prostitusi Online Di Kota Yogyakarta Dalam Persfektif Nilai Kemanusiaan Yang Adil Dan Beradab. Jurnal Kewarganegaraan, 17(1), 27-34. https://doi.org/10.24114/jk.v17i1.14208

Nurgiansah, T. H. (2020c). Pelatihan Penulisan Artikel Ilmiah Bagi Mahasiswa PPKn Universitas PGRI Yogyakarta. JNPM: Jurnal Nasional Pengabdian Masyarakat, 1(1), 16-23.

Nurgiansah, T. H. (2021a). Partisipasi Politik Masyarakat Sleman di Masa Pandemi Covid-19 dalam Konteks Pendidikan Kewarganegaraan. Jurnal Civic Hukum, 6(1), 1-9.

Nurgiansah, T. H. (2021b). Pelatihan Penelitian Tindakan Kelas Bagi Guru Pendidikan Kewarganegaraan Di Sekolah Menengah Atas Se-Kabupaten Bantul. BERNAS: Jurnal Pengabdian Kepada Masyarakat, 2(1), 28-33. https://doi.org/10.31949/jb.v2i1.566

Nurgiansah, T. H. (2021c). Pemanfaatan E-Learning Dalam Pembelajaran Pendidikan 
Kewarganegaraan. JINTECH: Journal of Information Technology, 2(2), 138-146.

Nurgiansah, T. H. (2021d). Petuah Pendidikan Kewarganegaraan Dalam Kontestasi Politik. AoEJ: Academy of Education Journal, 12(1), 39-47.

Rachman, F., Nurgiansah, T. H., \& Kabatiah, M. (2021). Profilisasi Pendidikan Kewarganegaraan dalam Kurikulum Pendidikan Indonesia. Edukatif: Jurnal Ilmu Pendidikan, 3(5), 29702984.

Rachman, F., Ryan, T., Kabatiah, M., Batubara, A., Pratama, F. F., \& Nurgiansah, T. H. (2021). Pelaksanaan Kurikulum PPKn pada Kondisi Khusus Pandemi Covid-19. Jurnal Basicedu, 5(6), 5682-5691.

Safrina. (2020). Jaga Protokol Kesehatan, RSUDZA Terapkan Disiplin Antrian. Pemerintah Aceh, Kesehatan. Retrieved from https://acehprov.go.id/berita/kategori/kesehatan/jagaprotokol-kesehatan-rsudza-terapkan-disiplin-antrian

Sari, D. S. (2021, October). Membangun kepedulian di masa covid-19 melalui program gerak sedekah millennial di Desa Tegalkamulyan Cilacap. View of Membangun Kepedulian di Masa covid-19 melalui program Gerak Sedekah millennial di Desa Tegalkamulyan Cilacap. Retrieved November 16, 2021, from https://journal.iainlangsa.ac.id/index.php/connection/article/view/3315/1766.

Setyani, J. (2021, May 24). Minimnya Kesadaran Mengantri Masyarakat Indonesia - reportase.tv berita news reportase,TV. reportase.tv. Retrieved November 16, 2021, from https://reportase.tv/minimnya-kesadaran-mengantri-masyarakat-indonesia/.

Simanjuntak, D., \& Fitriana, R. (2020, September 30). Gegar Budaya, Adaptasi, dan Konsep Diri Sumber Daya Manusia Pariwisata dalam Menyongsong Era New Normal. society.fisip.ubb.ac.id. Retrieved November 16, 2021, from https://society.fisip.ubb.ac.id/index.php/society/article/download/200/169/.

Suseno, I. W. (2018). Pendidikan Anak Model Orang Tua di Jepang. Kiryoku, 2(1), 58-64. https://doi.org/10.14710/kiryoku.v2i1.58-64

Wiwoho, L. H., \& Erdiansyah, R. (2020, March 30). Social distancing Dan Hambatannya Dalam Sosio-Kultural Indonesia. KOMPAS.com. Retrieved November 16, 2021, from https://www.kompas.com/tren/read/2020/03/30/142329065/social-distancing-danhambatannya-dalam-sosio-kultural-indonesia?page=all.

Yunizar, F. (2019). Menumbuhkan Rasa Malu (Shame) dalam Menanggulangi Kenakalan Remaja di Lembaga Pendidikan. Al-Bahtsu: Jurnal Penelitian Pendidikan Islam, 4(2), 187 192. http://dx.doi.org/10.29300/btu.v4i2.2678 